\title{
Governance of the Asian Infrastructure Investment Bank in Comparative Context
}

\author{
Natalie Lichtenstein*
}

\begin{abstract}
The Asian Infrastructure Investment Bank (АІІВ) was launched in 2016 with governance arrangements that build on the foundations of its progenitors, with adaptations and updates reflecting AIıB's own focus and founders. AIIB follows multilateral development banks (MDBs) such as the World Bank, Asian Development Bank, European Bank for Reconstruction and Development and Inter-American Development Bank in its governance structure (Board of Governors, Board of Directors and President). AIIB includes expanded powers for the Board of Governors to add flexibility in areas such as new types of financing and assistance to non-members. AIIB's Board of Directors serve on a part-time non-resident basis, with detailed powers for policy, oversight and delegation. AIIB's President is limited to two terms. AIIB's voting structure is tied to shareholding but less so than in many other MDBs, as basic votes for all members and Founding Member Votes for founders reduce the impact of shareholding to less than 90 percent of total voting power. The underlying comparisons with other MDBs are spelled out in detail in this chapter, summarizing AIIB's heritage and innovation in governance.
\end{abstract}

Governance in public international financial institutions began at least as far back as the July 1944 discussions at Bretton Woods, New Hampshire on the formation of the International Bank for Reconstruction and Development (IBRD) and the International Monetary Fund (IMF). Seventy years later, discussions were launched to create the Asian Infrastructure Investment Bank (AIIB), currently the newest multilateral development bank (MDB) to follow in

* Ms. Lichtenstein is an Adjunct Professor, Johns Hopkins School of Advanced International Studies, Washington, DC. She was formerly the Inaugural General Counsel for the Asian Infrastructure Investment Bank, and Assistant General Counsel at the World Bank. This article draws in part upon her book, see Natalie Lichtenstein, A Comparative Guide to the Asian Infrastructure Investment Bank (oup 2018). Email: lichtenstein@jhu.edu. 
IBRD's pioneering footsteps. In the intervening decades, a score of other MDBs has been established, each one adapting the MDв model and its governance characteristics to different goals in a different context, all with the objective of pooling financial contributions and commitments of countries into a new development finance institution.

This article traces the influence of MDB governance structures on the governance arrangements for AIIB, comparing relevant legal frameworks. After a brief introduction to АІІв (Section 1) and мDв Origins (Section 2), Section 3 describes AIIB's governing bodies (Board of Governors, Board of Directors, President) and Section 4 describes AIIB's decision-making rules (voting and majorities). Section 5 offers concluding observations.

1

AII B

AIIB was formally established in January 2016 as a USD10o billion MDBfinancing infrastructure for the development of Asia, from the Pacific to the Mediterranean. Its 57 founders, mostly countries from Asia and Europe, decided to address this goal by setting up a new MDB, drawing from both successes and dissatisfactions at existing MDBs. This decision reflected the priority they placed on the urgency of mobilizing finance for infrastructure, rather than a focus on a new institution for its own sake. They expected a quicker startup by adapting an existing structure, instead directing the energy of the negotiators (and the АІІв board and management), to find innovative ways to improve upon the perceived shortcomings in the framework and operation of existing MDBS.

Indeed, each $\mathrm{MDB}$ in turn has been built upon the foundations of its predecessors. For AIIB, as for others, credibility for a brand new financial institution could be enhanced by reliance on arrangements that were known, workable and respected. Investors and rating agencies could more easily assess AIIB through common $\mathrm{MDB}$ frameworks. Both public and private sector clients could more easily compare recognizable financial products and operational policies. Moreover, familiar yet improved operating processes could be less burdensome, while harmonization with other MD B practices would be in line with current MDв coordination efforts. The vast and varied MDв experiences could be utilized for operations, administration and legal interpretations, while aiming at greater effectiveness.

At the two-year milestone (January 2018), these benefits of adapting the MDB model appear to have been borne out in reality. As an international organization, AIIB counts among its first 84 approved members countries in East 
Asia, South Asia, Central Asia, Western Asia and Oceania as well as non-Asian countries in Europe, Africa, Latin America and North America. AIIB's investments in infrastructure in its first two years totaled over USD 4 billion. ${ }^{1}$ As an international financial institution, AIIB enjoys a triple-A rating in international capital markets. ${ }^{2}$ AIIB's multinational management and staff have taken up residence at its headquarters in Beijing, home of its initiator and largest shareholder, the People's Republic of China.

Before turning to a comparison of AIIB's governance with governance provisions at other MDBs, a short introduction to these institutions is in order. This Section summarizes the progression of MDBs. Sections 3 and 4 will then discuss the similarities and differences found in the АІІв Charter and the Charters of those MDBs that serve as the principal comparators for the design of AIIB governance. ${ }^{3}$

\subsection{World Bank (IBRD) 1945}

The IBRD Charter was negotiated by 44 country delegations at the same 1944 conference as the IMF charter, and had been the subject of several years of preceding discussions, principally between the US and the UK. ${ }^{4}$ IBRD took second place in urgency and interest to the IMF, in the economic, financial

1 See the list of projects and approval dates on the AIIB website, www.aiib.org. Table 4.1 in Lichtenstein $(n *)$ summarizes the AIIB investment operations approved in 2016-2017.

2 See for example the Standard and Poor's rating assignment in $\mathrm{n} 59$ below.

3 The Articles of Agreement of the Asian Infrastructure Investment Bank (dated 29 June 2015, entered into force 25 December 2015) are referred to here as the Аіпв Charter.

The constituent documents for other MDBs are referred to as their Charters, as follows:

- IBRD Charter (Articles of Agreement of the International Bank for Reconstruction and Development, dated 27 December 27 1945, as amended through 2012).

- ЕІв Charter (Statute of the European Investment Bank, version dated 1 July 2013).

- IADB Charter (Agreement Establishing the Inter-American Development Bank, dated 8 April 1959, as amended through 1995).

- AfDB Charter (Agreement Establishing the African Development Bank, dated 4 August 1963, as amended through 2001).

- ADB Charter (Agreement Establishing the Asian Development Bank, dated 4 December 1965).

- EBRD Charter (Agreement Establishing the European Bank for Reconstruction and Development, dated 29 May 1990, as amended through 2012).

4 For a general history of the negotiations that led to the establishment of the IMF and IBRD, see Ed Conway, The Summit: Bretton Woods, 1944 (Pegasus Books 2014). For a succinct legal 
and political disruptions of the ongoing World War. IBRD's dual purposes of reconstruction and development were a response to the perceived needs for a post-war world, and were unique at the time, as was its structure. Several key IBRD financial and governance provisions can be seen in an earlier unsuccessful effort to create an Inter-American Bank, including the all-important capital structure and voting patterns. ${ }^{5}$ IBRD's original emphasis on providing guarantees of private sector loans derived from pre-war financial situations, but changed quickly to an emphasis on government guaranteed loans, always for productive purposes.

To illustrate how much the international arena was in flux at that moment, note that the IMF and IBRD negotiations predated the finalization of the charter of the United Nations in $1945 \cdot{ }^{6}$ As of 2017 , both the IMF and IBRD have 189 members, nearly every current UN member. ${ }^{7}$ In 1947, US shareholding gave it a controlling voting power in IBRD of 35 percent; today, US voting power hovers just above the 15 percent minimum necessary to keep a veto on Charter amendments that require an 85 percent majority. ${ }^{8}$

history of the IBRD Charter, see Henry J Bitterman, "Negotiation of the Articles of Agreement of the International Bank for Reconstruction and Development" (1971) 5 Intl Lawyer 59.

5 The Inter-American Bank (IAB) was a proposed intergovernmental institution, under a convention signed in 1940 by the United States and eight Latin American countries (Bolivia, Brazil, Colombia, Dominican Republic, Ecuador, Mexico, Nicaragua and Paraguay). Domestic approvals for US participation proved elusive and the IАв did not come into existence. See Eugenio Diaz-Bonilla and Maria Victoria del Campo, A Long and Winding Road: The Creation of the Inter-American Development Bank (no publishing information 2010) 32-41. The IАВ would have had a corporate structure, with paid-up capital at $5^{\circ}$ percent and the remainder subject to call with three months' notice. Voting power would have been based on shareholding, with a type of basic votes for all. The IAB would have been authorized to make loans, take deposits and issue bonds, among its other purposes and powers. US Department of State Bulletin (1940), 516 (listing Inter-American Bank By-Laws, s 2A and 5A). IAB's corporate and capital structure may have been derived from the Bank for International Settlements, the first such international financial institution, established in 1930 with a structure based on a Swiss company limited by shares. For more discussion of the impact of IAB on the IBRD setup, and through it, to the other MDBs, see Eric Helleiner, Forgotten Foundations of Bretton Woods: International Development and the Making of the Postwar Order (Cornell UP 2014), especially ch 2, and Bitterman (n 4) 61-62.

6 The Charter of the United Nations (done in San Francisco in June 1945, entered into force on 24 October 1945) 1 UNTS XVI.

7 IMF membership is a prerequisite for IBRD membership. IBRD Charter, art II, S 1. Andorra, Cuba, Democratic People's Republic of Korea, Liechtenstein and Monaco are UN members but not IMF and IBRD members.

8 The IBRD Charter, art VIII (a), requires approval by three-fifths of members having $85 \%$ of total voting power for its amendment. The original IBRD threshold was 80 percent; the IBRD Charter was amended in 1989 to change to $85 \%$, in connection with an agreement for the 
An important facet of IBRD's history has been the creation of affiliated institutions to take on development-related functions that were beyond its Charter-based remit-rather than taking the route of Charter amendment. IBRD was joined by a separate yet affiliated institution established in 1960 to provide concessional finance to the less developed areas of the world, the International Development Association (IDA). Together, IBRD and IDA are often referred to as the World Bank. In addition, the World Bank Group refers to IBRD, IDA, the International Finance Corporation (IFC, a private investmentoriented affiliate, established in 1956 to provide finance without government guarantee and, later, equity investment), the Multilateral Investment Guarantee Agency (MIGA, a political risk insurance affiliate, established in 1988) and the International Centre for the Settlement of Investment Disputes (ICSID, an affiliate for investor-State dispute settlement, established in 1965). MDв Charters that came after the IBRD Charter have often included some of these additional functions from the start, such as non-government lending, equity investment and concessional funding for less developed countries.

\subsection{European Investment Bank (EIB ) 1957}

EIB grew out of years of discussions within Europe on its post-war development that included, inter alia, concerns over potential competition with the recently-established IBRD and its new private sector arm, IFC. ${ }^{9}$ ЕIB was established to contribute to the balanced and steady development of the European internal market, through loans and guarantees. ${ }^{10}$ EIB's overall governance framework was built upon the IBRD Charter, such as its Board of Governors and Board of Directors, while many other governance aspects were entirely new, such as the Management Committee and the non-resident status of the Board of Directors. ${ }^{11}$ EIB was the first of the MDBs described here to adapt the IBRD model, though EIB's structure and function as an institution of the European Union (EU) differentiate it from the others. In that sense, it had a more general influence on the governance design at AIIB.

US voting power to drop below 20 percent (and, among others, Japan to increase its voting power, becoming the second largest shareholder).

Regarding the comparison and competition with IBRD and IFC, see European Investment Bank (EIB), The Bank of the European Union: The EIB, 1958-2008 (European Investment Bank 2008) 32-34. art 309 (ex art 267, Treaty establishing the European Community). The Е вв Charter was amended to allow for equity investments by EIB itself in 2009. EIB art 18-2. 


\subsection{Inter-American Development Bank (IADB) 1959.}

IADB was founded in 1959, yet its story can be traced through the preceding century of the economic and political history of Latin America as a region with its northern neighbor, the US. An "International American Bank" had been proposed in 1890 as a private regional banking institution, and later, an intergovernmental financial institution, the Inter-American Bank, nearly came to life in 1940, as noted earlier. ${ }^{12}$ Latin American countries renewed the push for a similar institution in the 1950s, when they did not find that IBRD fully met regional needs in its early years. ${ }^{13}$ Early on, the proposal for this new regional institution was not initially supported by the US, likely concerned about competition with IBRD for support. Then, the winds of US foreign policy changed with tensions in the region and brought the US to the negotiating table, becoming IADB's key funder and largest shareholder. ${ }^{14}$

IADB's purpose is to contribute to the economic and social development of its regional member countries, through loans and guarantees; filling a gap in the IBRD Charter, technical assistance is also expressly authorized. ${ }^{15}$ While IADB's initial governance framework mirrored that of IBRD, later innovations came from IADB's regional character. Originally, IADB members were all regional countries and only members of the Organization of American States (OAS). Following a decline in US financial support in the late 1960s, the IADB Charter was amended in the 1970s to allow Canada and other non-oAs regional countries to join, and then to bring in non-regional members and their capital (Europe and Japan, initially). IADB thus led the way with Charter clauses specifying the shareholding for regional developing members (now $5^{0.005}$ percent), the US (now 30 percent) and Canada (4 percent). IADв also pioneered

12 See Diaz-Bonilla and del Campo (n 5) 4-11 (International American Bank) and 32-41 (Inter-American Bank).

13 Ibid $58-59$ (dissatisfaction with existing international financial institutions).

14 In earlier times, the United States reportedly was cool to the IADB proposal until US bilateral activities in Latin America met with public outcry. See Diane Tussie, The Multilateral Development Banks, Volume 4: The Inter-American Development Bank (Lynne Rienner Publishers 1995) 18-19, citing as a motivating factor for US participation in IADB negotiations the hostility encountered by US Vice President Richard Nixon in his $195^{8}$ trip to Latin America. It has also been suggested that final US agreement to join the IADB negotiations was timed days before a public proposal by US President Eisenhower to establish an Arab development institution in the wake of US problems in Lebanon and elsewhere in the Middle East in 1958. See Diaz-Bonilla and del Campo (n 5 ) 68-69. The US share of IADB capital at its inception was $42 \%$ and it was the largest funder of the Fund for Special Operations, the soft-loan window.

15 IADB Charter, art I, $\mathrm{s} 1$ (purpose), art III, s 4 (operations) and art VI (technical assistance). 
the introduction of specific regional majority requirements for key decisions. ${ }^{16}$ Interestingly, IADB members also established a separate entity for private sector and equity investment, the Inter-American Investment Corporation, as EIB had with its European Investment Fund, both parallels to IBRD's addition of the IFC.

\subsection{African Development Bank (AfDB) 1963}

Regional economic history also lay behind the formation of AfDB as an African financial institution in the post-colonial era. The UN Economic Commission for Africa played a seminal role in AfDB's establishment (as its Asian equivalent did for Asian Development Bank). Nonetheless, it was the economic and political relations among different groups of African countries that determined the timing and contours of the bank that emerged. Relations with developed countries had an impact regarding decisions to join the bank and on forms of concessional financing (e.g., relations with France and the US). ${ }^{17}$ However, non-regionals were not part of the AfDB membership discussions until much later.

AfDB's purpose is to contribute to the sustainable economic development and social progress of its regional members, through loans, guarantees and equity investment. ${ }^{18}$ AfDB's overall governance arrangements were also based on the IBRD model, with adjustments over time in response to its own institutional experience; for instance, the President was originally selected by the Board of Directors, as at IBRD, and later this was changed to election by the Board of Governors, as at IADB and АDB. ${ }^{19}$ The need for concessional finance led to the innovative African Development Fund, a separate entity jointly owned by AfDB and non-regional donors. ${ }^{20}$ Then, in the 1980s, AfDB followed the IADB

16 For IADB regional shareholding requirements, see IADB art VIII, s 4 (b) and the detailed listing in $\mathrm{n} 102$.

17 Robert KA Gardiner and James Pickett, The African Development Bank 1964-1984 (The African Development Bank 1984) 8-13.

18 AfDB Charter, art 1 (purpose) and art 14-1 (methods of operation). Technical assistance is also among AfDB's functions. AfDB Charter, art 2-1 (e). The word "sustainable" was added in 2001. AfDB Board of Governors' Resolution No. B/BG/2001/o8, Amendments to the Agreement Establishing the African Development Bank, adopted 29 May 2001, entered into force 5 July 2002.

19 AfDB Charter, art 36 (as amended in 1979, see note 79 for details). The appointment process for Vice-Presidents was also changed in response to AfDB's experience. See note 83 for details.

20 The African Development Fund (AfDF) was originally set up as an AfDB special fund with AfDB funding, as the response of potential donors was not encouraging. By 1972, the AfDF was established as a separate international institution, by AfDB and non-regional donors. 
experiment and opened up AfDB itself to non-regional members and their capital contributions, limiting their share (now 40 percent non-regional and 60 percent regional). ${ }^{21}$

\subsection{Asian Development Bank (ADB) 1965}

A proposal for a regional development bank in Asia had been floated by Japan in the early 196os, without gaining traction. Around the same time, a similar idea was under discussion among other Asian countries through the UN Economic Commission for Asia and the Far East. Like the Latin America countries proposing IADB a decade earlier, they had found the extent of IBRD support for their development less than expected. ${ }^{22}$ Similarly, the US was an important player and potential funder in Asia as well, and yet was also initially cool to the ADB proposal, not perceiving the depth of the unmet needs, and concerned about competition with IBRD. Again, the winds of US foreign policy shifted (in connection with the US war in Southeast Asia), buoying the ADB proposal to a successful conclusion with full US support. ${ }^{23}$ Japan and the US have continued since as the two largest shareholders and supporters of ADB.

ADB was established to foster economic growth and co-operation in Asia and to contribute to the economic development of developing member countries. ${ }^{24}$ ADB's governance provisions are closely modelled on the IBRD provisions and have not been amended. The АDв Charter was the first to include both regional and non-regional members from the outset but does not require specific regional majorities for its qualified majority decisions; it does ensure that regional shareholding will stay at 60 percent, ${ }^{25}$ preserving the regional character of the institution. The ADв Charter also permits all types

See Andres Rigo Sureda, "The Law Applicable to the Activities of International Development Banks" in (2004) Collected Courses of The Hague Academy of International Law 308 , paras $410-420$.

21 AfDB Charter, art 5-4.

22 At the time, a high proportion of World Bank Group financing for Asia was directed to larger Asian developing countries (65 percent of IBRD and 95 percent of IDA financing for Asia went to India and Pakistan). Dick Wilson, A Bank for Half the World, The Story of the Asian Development Bank 1966-86 (Asian Development Bank 1987) 6.

23 After initial opposition, the United States warmed to the ADв proposal only after the United States sought to improve its standing in Southeast Asia after the start of the Vietnam War. See Dick Wilson (n 22) 12-13, citing US President Lyndon Johnson's change of view on ADB as part of a large commitment of US assistance to Southeast Asia in April 1965 .

24 AD в Charter, art 1 (purpose) and art 11 (methods of operation).

25 The regional shareholding minimum is found in ADB Charter, art 5-1. 
of operations (loans and guarantees for both public and private entities and equity investment) as well as the establishment of special funds (often a mechanism for concessional finance contributed by donors) and provision of technical assistance. ${ }^{26}$ The drafting of the ADB Charter took into account the IBRD, IADB and AfDB Charters, and served as a foundation for the EBRD Charter and later the АІІв Charter.

\subsection{European Bank for Reconstruction and Development (EBRD) 1990}

Following ADB by some 25 years, EBRD began as a regional initiative among Europeans, in response to the newly emerging need for assistance to Central and Eastern Europe. With a longstanding regional investment bank (ЕІВ) already in operation, EBRD was set up with a specialized set of goals: "to foster the transition towards open market-oriented economies and to promote private and entrepreneurial initiative in the Central and Eastern European countries committed to and applying the principles of multiparty democracy, pluralism and market economics."27 Politics was no less a part of EBRD's creation than for its predecessors, reflecting differing views of key European protagonists (France, Germany, UK), European institutions (the EU and EIB were original EBRD members), and the US and Japan. ${ }^{28}$

To serve its specific purposes, EBRD is authorized to make loans to and invest in the equity capital of private enterprises, and state-owned enterprises that meet certain conditions; guarantees in some circumstances and technical assistance are also expressly authorized. ${ }^{29}$ Also specifically designed for EBRD is the requirement that not more than 40 percent of its committed loans, guarantees and equity investment be provided to the state sector. ${ }^{30}$ While its operational mandate is unique, EBRD's governance arrangements are closely aligned with its predecessors. For both political and economic reasons, EBRD was established with a combination of regional and non-regional shareholders from the start. EBRD eventually found itself undertaking Charter amendments to expand its countries of operation beyond the geographical confines

26 АDв Charter, art 11 (methods of operation), art 19 (Special Funds) and art 21 (vi)(technical assistance).

27 EBRD Charter, art 1.

28 Stephen Weber, "Origins of the European Bank for Reconstruction and Development," (1994) 48 Intl Organization 1, 15-16, also pointing out that US skepticism about regional banks was long-standing and deep.

29 EBRD Charter, art 11-1.

30 EBRD Charter, art 11-3. 
of Central and Eastern Europe to include Mongolia and the Southern and Eastern Mediterranean. ${ }^{31}$

\subsection{AIIB Establishment}

With these precedents in mind, let us turn to the details of AIIB's establishment. The specific proposal for AIIB was floated in October 2013 by Chinese President Xi Jinping during a Southeast Asian visit, focused on the infrastructure needs of Asia. Though there had been some earlier similar proposals, ${ }^{32}$ the October 2013 proposal took shape, and by October 2014, 22 Asian countries, organized by China, had concluded a Memorandum of Understanding on Establishing the Asian Infrastructure Investment Bank. These countries, joined in the subsequent Charter negotiations by 37 others from Asia, Europe, Africa and Latin America, agreed on the AIIB Charter, signed in June 2015. AIIB's largest shareholder at inception was China with over 25 percent of the voting power, followed by India (around 8 percent) and Russia (around six percent); non-regional members hold nearly 25 percent of the shareholding. Yet the two largest shareholders in IBRD, ADB and EBRD were notably absent (the US and Japan). Twenty-seven new АІІв members were approved in 2017, bringing the total to 84 (48 regional and 36 non-regional).

AIIB was established "to foster sustainable economic development, create wealth and improve infrastructure connectivity in Asia by investing in infrastructure and other productive sectors" and to promote regional cooperation and partnership in addressing development challenges. ${ }^{33}$ Its scope of operations reflects the experience of others, so that it includes loans, guarantees, equity investment, Special Fund operations and technical assistance.

31 EBRD Board of Governors' Resolution No. 90, Amendment to the Agreement Establishing the Bank in order to Admit Mongolia as a Country of Operations, adopted 30 January 2004, entered into force 15 October 2006. EBRD Board of Governors' Resolution No. 137, Amendment of the Agreement Establishing the Bank in order to Enable the Bank to Operate in Countries of the Southern and Eastern Mediterranean, adopted 30 September 2011, entered into force 12 September 2013.

32 Earlier proposals included a 2005 report from the UN Economic and Social Commission for Asia and the Pacific that suggested the establishment of an Asian Investment Bank, adapted from the EIв model, to meet the region's infrastructure needs and promote regional development. See UN Economic and Social Commission for Asia and the Pacific, Implementing the Monterrey Consensus in the Asian and Pacific Region: Achieving Coherence and Consistency (United Nations 2005) 154.

In 2009, a Chinese think-tank suggested the formation of a new development bank focused on infrastructure. See Mike Callaghan and Paul Hubbard, "The Asian Infrastructure Investment Bank: Multilateralism on the Silk Road," (2016) 2 China Economic J 116, singling out the 2009 proposal by the China Center for International Economic Exchanges. АІІв Charter, art 1-1. 
Themes. This highly selective overview reveals some themes that are echoed in the more recent AIIB story. There is considerable reluctance at every turn to start a new institution. One can see the US as an exemplar of this view (for IADB, ADB, EBRD and AIIB ), but the sentiment is widely shared. There are also different perceptions of the weight of problems with existing MDBs compared to costs and uncertain dynamics in new ones. It is often the regional countries for whom the dissatisfaction with current options propels the establishment of a new entity. Consider here the Latin American countries wanting IADB to take on social projects, public investment in industry and local currency lending, or the smaller southeast Asian nations making the case for ADB, as IBRD/IDA funding was directed to larger former colonies. ${ }^{34}$ The driving force of geopolitics proved inescapable in each case.

Resistance from existing MDBs is not surprising. For IBRD, the rise of the regional development banks has been described as "at once a tribute and a rebuke." 35 Yet, the existing institutions also helped with the design and drafting of subsequent Charters, and, once the new institutions were established, with the details of getting up and running. Another theme is the importance of the scope of membership, especially in the interaction between finance and governance, as seen in the opening to non-regional members for IADB and AfDB.

Not mentioned here are a number of other MDBs and similar international financial institutions, many subregional and some more specialized. While not discussed in any detail, they form part of the MD в family and offer variations in governance and other provisions. The Caribbean Development Bank, Islamic Development Bank, and Black Sea Trade and Development Bank operate under charters and governance structures that are largely comparable to the MDBs described above, in their specific geographic areas. Other subregional institutions include the Andean Development Bank (CAF), Nordic Investment Bank and the Council of Europe Development Bank, among others. The International Fund for Agricultural Development (IFAD) is another source of development finance, as a UN specialized agency with worldwide operations.

AIIB shares its overall governance structure with many other MDBs, with a common hierarchy of three governance levels: Board of Governors, Board of

\footnotetext{
34 See n 14, n 22 and n 23.

35 Edward S Mason and Robert E Asher, The World Bank Since Bretton Woods (The Brookings Institution 1973) 578 .
} 
Directors and President. The Board of Governors is the Bank's highest authority, composed of one Governor appointed by each member, meeting annually. The Board of Directors is responsible for the direction of the general operations of the Bank and is composed of Directors elected by one or more Governors representing particular members, meeting at least quarterly. The President, elected by the Board of Governors, conducts the current business of the Bank, under the direction of the Board of Directors.

\subsection{Board of Governors}

The AIIв Board of Governors meets annually, as do other Boards of Governors in well-publicized Annual Meetings; other meetings can be called by the Board of Governors or Board of Directors, though this is very rare in MDв practice. ${ }^{36}$ Most frequently, decisions of the Board of Governors are taken in a vote without a meeting, on recommendation by the Board of Directors, and for AIIB, electronic meetings may take place in special circumstances (a new provision). ${ }^{37}$ The Board of Governors elects its Chairman and Vice-Chairman at each annual meeting, and can establish committees that report to the Board. ${ }^{38}$

Under the АІІв Charter, all powers of the Bank are vested in the Board of Governors, as is the case in other MDBs. ${ }^{39}$ The Board of Governors may delegate most of its powers to the Board of Directors; certain key powers are specified in the Charter and cannot be delegated (known as reserved powers). ${ }^{40}$ The reserved powers of the АІІв Board of Governors listed in the AIIB Charter are comparable and often identical to the reserved powers of other $\mathrm{MDв}$ Boards of

36 АІІв Charter, art 22-1 (composition) and 24-1 (meetings). For the comparable provisions in others, see generally AfDB Charter, arts 30 and 31; ADв Charter, arts 27 and 29; EBRD Charter, arts 23 and 25; IADв Charter, art viII, $\mathrm{s} 2$ and IBRD Charter, art V, $\mathrm{s} 2$.

37 АІІв Charter, art 24-3, and АІІв Rules of Procedure of the Board of Governors, s 2 (c). Another recent example of electronic meetings, for the Board of Directors, can be found in the By-Laws of the European Stability Mechanism, s 3-8 (8 December 2014). See also the Statutes of the Bank for International Settlements, dated 20 January 1930, as amended through 7 November 2016, art 31-2.

38 АІІв Charter, art 22-2 and АІІв Rules of Procedure of the Board of Governors, ss 6 (b) and 9. In December 2017, AIIB's Board of Governors added a provision to its Rules of Procedure (Section 7) for an Advisory Group to advise the Chair on urgent procedural issues related to meetings, and other tasks; the Group is comprised of the current Chair, the previous Chair and the Vice Chairs. This new mechanism is comparable to the procedures committees set up for some other MDв annual meetings; on its face, the Group appears potentially simpler and more responsive, though less broad in its composition.

39 АІІв art 23-1. AfDB Charter, art 29-1; АDв Charter, art 28-1; ЕвRD Charter, art 24-1; IADB Charter, art viII, s 2 (a); and IBRD Charter, art v, s 2 (a).

AIIB Charter, art 23-2. 
Governors. ${ }^{41}$ In addition, the AIIB Charter assigns a number of other powers solely to the Board of Governors, and these cannot be delegated either. Most of these specifically assigned powers are new for AIIB, and they include: variations in the classification of the Asia region; change to the non-resident status of the Board of Directors; variation in the 75 percent regional shareholding requirement; allocation of net income to other purposes; increase in the lending limit; establishment of subsidiaries; framework for trust funds; financing for non-member recipients; and new types of financing. ${ }^{42}$

At the start, the АІІв Board of Governors indeed delegated to the АІгв Board of Directors all of its powers that are not reserved or specifically assigned, following the practice of the others. ${ }^{43}$ One difference in АІІв powers is that the power to approve arrangements for cooperation with other international organizations is directly assigned to the Board of Directors in the АІІв Charter; in others, it is often reserved to the Board of Governors. ${ }^{44}$ In practice, many of these cooperation arrangements are now administrative and technical in nature, and can be more appropriately decided by the Board of Directors, or by the management under guidance from the Board of Directors.

\section{2 $\quad$ Board of Directors}

The overall structure and powers of the AIIB Board of Directors are very similar to its predecessors, with some notable distinguishing features. These include

41 See AfDB Charter, art 29-2; АDв Charter, art 28-2; Е вRD Charter, art 24-2; IAD в Charter, art VIII, s 2 (b); and IBRD Charter, art V, s 2 (b).

42 Specifically assigned powers of the АІІв Board of Governors can be found in the АІІв Charter as follows: Asia definition (art 1-2); exceptions to $75 \%$ regional shareholding, and review of capital stock (arts 5-2 and 5-3); non-par value shares (art 7-1); non-member recipient (art 11-1(b)); new types of financing (art 11-2 (vi)); increase in lending limit (art 12-1); trust fund framework (art 16-7); subsidiaries (art 16-8); allocation of net income to other purposes (art 18-1); size or composition of the Board of Directors (art 25-2); number of constituency members for second Alternate Director (art 25-3); change in nonresidential status of the Board of Directors (art 27-1); and extension of the final date for Signatories to ratify (art 58-1).

43 АІІв By-Laws, $s$. This Section further provides that the Board of Directors shall not take any action pursuant to powers delegated by the Board of Governors which is inconsistent with any action taken by the Board of Governors. This delegation and proviso are also common. See AfDB General Regulations art 4-1; ADв By-Laws s 8; EBRD By-Laws s 8 (a); IADB By-Laws s 4; and IBRD By-Laws 14.

44 АІІв Charter, art 35 . The power to approve general agreements with other international organizations is a reserved power of the Board of Governors in AfDB, ADB, EBRD, IADB and IBRD, in varying terms. See AfDB Charter, art 29-2; ADB Charter, art 28-2; EBRD Charter, art 24-2; IAD B Charter, art VIII, s 2 (b); and IBRD Charter, art v, s 2 (b). 
the Board's non-resident status and expanded powers of delegation and oversight that go with it.

\subsubsection{Size and Constituency Structure}

The size of м Вв Boards of Directors varies considerably, and this can have an impact on the openness of discussions, cohesiveness and consensus-building. Each Director casts the votes of one or more members in a constituency; often, members with large voting power have their own Director (single member constituency) or may dominate the Directorship in a group constituency.

The AIIB Board of Directors has 12 Directors (representing 61 members, with 23 more approved for membership, as of January 2018), with one single member constituency; nine Directors are regional and three Directors are nonregional, reflecting the 75 percent regional shareholding in АІІв. ${ }^{45}$ The size and composition of the АІІв Board of Directors may be changed by a decision of the АIIв Board of Governors. ${ }^{46}$ These basic provisions for the composition of the AIIв Board of Directors are comparable to other MDBs in many respects. ${ }^{47}$ Often, the proportion of regional and non-regional Directors is specified, usually in line with the proportion of regional and non-regional shareholding; the exception is IBRD which is global and does not categorize members as regional and non-regional. The table below compares Board composition, in terms of number of Directors, members represented, regional/non-regional proportions and single member constituencies.

Composition of MDв Boards of Directors (January 2018)

\begin{tabular}{|c|c|c|c|c|c|}
\hline Institution & $\begin{array}{l}\text { Number of } \\
\text { Directors }\end{array}$ & $\begin{array}{l}\text { Number of } \\
\text { Members }\end{array}$ & $\begin{array}{l}\text { Regional } \\
\text { Directors } \\
\text { (Members } \\
\text { represented) }\end{array}$ & $\begin{array}{l}\text { Non-Regional } \\
\text { Directors } \\
\text { (Members } \\
\text { represented) }\end{array}$ & $\begin{array}{l}\text { Single } \\
\text { Member } \\
\text { constituencies }\end{array}$ \\
\hline AfDB & 20 & 81 & $13(54)$ & $7(26)$ & United States \\
\hline
\end{tabular}

45 АІІв Charter, art 25-1. As of 31 December 2017, only India has a single member constituency on AIIB's Board. (AIIB's largest member, China, is joined in its constituency by Hong Kong, China.) By March 21, 2018, AII B had 64 members.

46 АІІв Charter, art 25-2. A Super Majority vote is required: An affirmative vote of two-thirds of the total number of Governors, representing not less than three-fourths of the total voting power of the members, as per art 28-2 (ii).

47 AfDB Charter, arts 33 and 34; АDв Charter, arts 30 and 32; EBRD Charter, arts 26 and 28; IAD B Charter, art VIII, s 3 ; and IBRD Charter, art v, s 4. 


\begin{tabular}{|c|c|c|c|c|c|}
\hline $\mathrm{ADB}^{\mathrm{a}}$ & 12 & 67 & $8(48)$ & $4(19)$ & $\begin{array}{l}\text { China } \\
\text { Japan } \\
\text { United States }\end{array}$ \\
\hline AIIB & 12 & $\begin{array}{l}61(+23 \\
\text { pending })\end{array}$ & $9(40+8)$ & $3(21+15)$ & India \\
\hline $\mathrm{EBRD}^{\mathrm{b}}$ & 23 & 68 & $\begin{array}{l}19 \\
(56+\mathrm{EIB}, \mathrm{EU})\end{array}$ & $4(10)$ & $\begin{array}{l}\text { France } \\
\text { Germany } \\
\text { Italy } \\
\text { Japan } \\
\text { United Kingdom } \\
\text { United States } \\
\text { EIB } \\
\text { EU }\end{array}$ \\
\hline $\mathrm{IADB}^{\mathrm{c}}$ & 14 & 48 & $11(28)$ & $3(20)$ & $\begin{array}{l}\text { Appointed: } \\
\text { United States } \\
\text { Canada }\end{array}$ \\
\hline$I_{B R D^{d}}$ & 25 & 189 & not applicable & & $\begin{array}{l}\text { Appointed: } \\
\text { China } \\
\text { France } \\
\text { Germany } \\
\text { Japan } \\
\text { United Kingdom } \\
\text { United States } \\
\text { Elected: } \\
\text { Russia } \\
\text { Saudi Arabia }\end{array}$ \\
\hline
\end{tabular}

a ADB began with a ten-member board. АDв Charter, art 30-1.

b EBRD's 23 Directors are grouped under EBRD Charter, art 26-1, in several ways. Eleven Directors represent Belgium, Denmark, France, the Federal Republic of Germany, Greece, Ireland, Italy, Luxembourg, the Netherlands, Portugal, Spain, the United Kingdom, EU and Е Ів. Twelve represent other members, of whom: four represent Central and Eastern European countries eligible for assistance from the Bank; four represent other European countries; and four represent non-European countries.

c At IADB, one Executive Director is appointed by the largest shareholder (US), not less than three are elected by nonregional members, and not less than ten others are elected by the remaining regional members.

d IBRD began with a 12-member board. The five largest shareholders each appoint their own Executive Director. Currently, UK and France are tied for fifth-largest shareholder and each appoint an Executive Director. 
Each АІІв Director appoints an Alternate Director, as is typical in the other MDBs. In AIIB, Directors representing five or more members may also appoint a second Alternate Director. ${ }^{48}$ This feature increases the opportunities for members in a constituency to participate directly in the work of the Board. ${ }^{49}$ Increasing the number of Board positions facilitates the designation by AIIB Founding Members of a Director or Alternate Director on a permanent or rotating basis, a privilege enshrined in the AІІв Charter. ${ }^{50}$ Both the second Alternate Director position and this privilege of designation aim at broadening the voice of smaller members in AIIB governance.

\subsubsection{Non-resident Board}

The Aпів Board of Directors is set up as a part-time board, on a non-residential basis, meeting periodically throughout the year as the business of the Bank requires. ${ }^{51}$ Regular meetings are held quarterly; meetings are called by the Chairman (АIIв President) or if requested by three Directors. ${ }^{2}$ The Board of Directors can also hold electronic meetings or vote without a meeting; decisions on an absence of objection basis are also permitted..$^{53}$

At the other MDBs discussed here, the Boards of Directors are resident (AfDB, ADB, EBRD, IADB and IBRD), with the Directors, Alternates and constituency staff based at the bank's headquarters and frequent meetings

48 АІІв Charter, art 25-3. Board of Governors' Resolution No. 8, Appointment of Additional Alternate Director, adopted 16 January 2016 provided that Directors who cast the votes of five or more members, whether through election or assignment of votes, shall be entitled to appoint an additional Alternate Director. This decision has now been enshrined in the AIIB By-Laws, s 10 (b). The IMF Charter has a similar provision, added in 2008. Articles of Agreement of the International Monetary Fund, dated 27 December 1945, as amended through 2016, art XII, s 3 (e).

49 In 2017, six constituencies had two Alternate Directors; once the additional approved members finalize membership and join constituencies (more than 20 were pending as of January 2018), other constituencies would likely have more than five members and be eligible for a second Alternate Director.

50 АІІв Charter, Schedule B, paragraph 10. Founding Members are those of the 57 Charter signatories that complete membership by a deadline (currently, 31 December 2018). АIIB Charter, art 3-1 (b). In January 2018, there were 54 Founding Members.

51 АІІв Charter, art 27-1. The Board of Governors can take a decision to alter the nonresidential basis, by a Super Majority vote (two-thirds of Governors representing not less than three-fourths of total voting power). There is a similar provision for the New Development Bank. Articles of Agreement of the New Development Bank (done 15 July 2014, entered into force 15 July 2015), art 12 (g).

$5^{2}$ AIIB By-Laws, s 10 (a) (quarterly meetings) and AIIB Charter, art 27-1 (calling meetings).

53 АІІв Charter, art 27-4 and AІІв Rules of Procedure of the Board of Directors, s 5 (d) and (e). A review of АІп Board minutes shows several virtual meetings and many absence of objection decisions. See Board of Directors (Meetings and Minutes) <www.aiib.org> accessed 31 December 2017. 
(sometimes twice a week at the World Bank Group, and usually twice a month at EBRD). Looking across the MDB world, however, the pattern is more varied. ЕІв has had a non-resident Board since its 1957 launch among six geographically-joined countries. ${ }^{54}$ Other international financial institutions that have functioned for decades with non-resident Board mechanisms include the Council of Europe Development Bank, the Andean Development Bank (CAF), Caribbean Development Bank, Nordic Investment Bank, Islamic Development Bank, Black Sea Trade and Development Bank, the International Fund for Agricultural Development, and most recently, the European Stability Mechanism and the New Development Bank. ${ }^{55}$

The non-resident Board model for AIIB drew much attention during AIIB's establishment process, as many commentators made comparisons to the better-known resident Board structures. ${ }^{56}$ Few noted the non-resident Boards in the international financial institutions listed above or commented upon the general practice in private companies. What is also less widely considered is the debate in MDв Charter negotiations until resident Boards were finally agreed. Famously, discussions on the IBRD and IMF Charters at Bretton Woods in 1944 featured a debate on residency, which was not settled in favor of resident boards until the inaugural meeting of the Boards of Governors in 1946. The debate included different views of Board functions, as well as cost:

[John Maynard] Keynes reopened the argument made at Atlantic City and Bretton Woods, that the directors should be men holding positions with their own governments, that they would be needed only occasionally to decide issues since the main work would be carried on by the Managing Director [IMF] and President [IBRD] and their staffs. The US representatives again urged that the directors and alternates would have to be available at all times for quick decisions, and that they could

54 Belgium, France, Germany, Italy, Luxembourg and the Netherlands. The Егв Board of Directors continues to be non-resident, even as ЕІв members today are the $28 \mathrm{EU}$ members.

55 In 2017, one rating agency, in assigning its AAA rating to AIIB, noted the non-resident Board and commented: "We do not see this as undermining its oversight or the decision making in any meaningful way." Standard and Poor's Research Update, "Asian Infrastructure Investment Bank Assigned 'AAA/A-1+' Rating: Outlook Stable” (18 July 2017).

56 The АІІв Charter not only provides explicitly for the Board of Directors to function "on a non-residential basis" in art 27-1, but also omits the references found in some other $\mathrm{MDB}$ charters to the Board functioning at the principal office of the Bank. See AfDB Charter, art 34-1; АD B Charter, art 32-1; EBRD Charter, art 28-1; IADB Charter, art VIII, s 3 (e); and IBRD Charter, art v, s 4 (e). 
develop the information and judgment needed for the business through board discussions. Keynes also argued that 48 salaries would impose an excessive burden, and that that number of men could be employed more usefully in their own countries, and since both Executive Directors and alternates were not needed all the time, they could divide work and salaries..$^{57}$

The US prevailed, and the IMF and IBRD were established with full-time, resident boards. Decades later, the issue of Board residency featured again in the negotiations on the AfDB Charter (1963), ADB Charter (1965) and the EBRD Charter (1990), before the resident board option was agreed. ${ }^{58}$ Governance reform discussions at the World Bank Group have also included proposals for a non-resident Board to clarify accountability and strengthen oversight, though no reforms in this area were adopted. ${ }^{59}$

\subsubsection{Board Powers}

Generally, the АІгв Board of Directors is responsible for the direction of the general operations of AIIB; ${ }^{60}$ the Board of Directors also exercises the powers delegated by the Board of Governors, as noted above. In addition, the Board of Directors is assigned other decisions throughout the AIIB Charter, including: interpretation of the АІІв Charter; arrangements with other international organizations (noted earlier); and appointment of Vice Presidents on the

57 Bitterman (n 4) 87. John Maynard Keynes led the delegation for the United Kingdom. For the IBRD and IMF Charters, Atlantic City refers to the pre-negotiation meetings in June 1944 and Bretton Woods refers to the negotiations in July 1944.

58 The issue of Board residency had been debated in the preparation of AfDB, and the Directors did not actually become resident until 1970. Gardiner and Pickett (n 17) 23. For ADB, during the negotiations on the Charter, cost-consciousness led to at least one proposal for a part-time Board. Wilson (n 22) 27. For EBRD, a majority of the European Community countries originally favored a non-resident board in order to economize on cost, as in the EIB. Paul A Menkveld, Origin and Role of the European Bankfor Reconstruction and Development (Graham \& Trotman 1991) 78. Apparently, the United States argued in favor of a resident board at EBRD to have a powerful voice in day-to-day functions, so as to assure that the vague compromises in negotiations would be implemented. Weber (n 28) 19.

59 One proposal to transform the World Bank Board from its resident, full-time status can be seen in the Zedillo Commission Report. High-Level Commission on Modernization of World Bank Group Governance, Repowering the World Bank for the 21st Century (World Bank 2009) Recommendation \# 2 (known as the Zedillo Commission Report for its Chairman, Ernesto Zedillo).

6о АІів Charter, art 26. The references to "operations of the Bank" in the АІІв Charter means all activities of the Bank, not just its investment operations. This terminology is common in other Charters. 
recommendation of the President. ${ }^{61}$ In addition, the AIIB Charter enumerates several specific powers of the Board of Directors-some similar to other MDBs, but several that set AIIв apart. ${ }^{62}$

- The АІІв Board of Directors prepares the work of the Board of Governors, such as preparing decisions for their approval. This function is regularly carried out by other MDв Boards of Directors. ${ }^{63}$

- The AIIв Board of Directors has the authority to establish the policies of the Bank; this is the practice elsewhere but it is not always explicit. Major operational and financial policies require Board approval by a majority representing not less than three-fourths of total voting power. ${ }^{64}$ The Board may, under Bank policies, delegate authority to the President, and decisions on such delegation also require approval of the Board of Directors by the same majority. This higher majority for certain decisions by the Board of Directors on policy matters recalls a provision in the EBRD Charter, requiring a two-thirds majority for general policy decisions, ${ }^{65}$ but is not found in other MDBs.

- The AIIB Board of Directors has the authority to take decisions on the financing operations of АІІв, and to delegate that authority to the President. ${ }^{66}$ Delegation decisions require the same 75 percent majority as for delegation

61 Decisions of the Board of Directors specifically mentioned in the AІІв Charter include: setting policies on percentage of an entity's equity investment (art 14-3); the appointment of Vice-Presidents (art 30-1); arrangements with international organizations (art 35); and, perhaps most importantly, the power to issue interpretations of the AII B Charter, with a final appeal to the Board of Governors (art 54).

62 Other мDв Charter provisions on the powers of the Board of Directors can be found in: AfDB Charter, art 32; ADв Charter, art 31; EBRD Charter, art 27; IADв Charter, art vilI, s 3 (a); and IBRD Charter, art v, s 4 (a). However, IADB and IBRD do not have enumerated powers in the same way.

63 АІІв Charter, art 26 (i). Only the later Charters spell this out as well. See AfDB Charter, art 32-1; ADв Charter, art 31 (i); and EBRD Charter, art 27 (i).

64 АІІв Charter, art 26 (ii).

65 EBRD Charter, art 29-3. The meaning of this provision at the time negotiations on the EBRD Charter were concluded is set out in the Chairman's Report on the Agreement Establishing the EBRD: "Delegates intended that, in the case of differing views on whether or not issues involved "general policy," decisions would be made by the Board on the basis of advice from the Legal Counsel. In general, decisions on individual operations would not involve such issues, but "general policy issues" would include, inter alia, the budget; the annual program of operations; borrowing policy, including borrowing limits; interest rate policy; exchange risk management policy; the drawing down of notes; underwriting policy and the organizational structure of the Bank."

66 АІІв Charter, art 26 (iii). АІІв operations include: making, co-financing, or participating in direct loans; equity investment; guarantees; use of Special Fund resources; technical assistance; and other types of financing determined by the Board of Governors under 
under policies. Many M DBs Boards exercise this approval authority, but only later Charters make this explicit; ${ }^{67}$ none provide for delegation. In practice, some MDв Boards of Directors decide on many operations on absence-ofobjection or other streamlined procedure, without actual discussion. Delegation at АІІв offers the possibility of a clearer division of responsibilities between the Board of Directors and the President, so that the Board of Directors can hold the President accountable for approvals of operations, according to the terms of its delegation. Accountability is less clear-cut when the Board takes the final decision itself. ${ }^{68}$ The importance of this possible delegation, however, can be seen in the higher majority required for its approval.

- The Board of Directors has the authority to approve AIIB's strategy, annual plan, and budget. ${ }^{69}$ How the content of the strategy and annual plan will evolve over time is likely to be worked out between the Board and management. Other MD Bs have similar planning documents without Charter-based requirements. The annual budgets are also approved by the Board of Directors and generally reported to the Board of Governors in other MDBs. ${ }^{70}$

- The AIIB Board of Directors is authorized to appoint committees, as in some other MDBs. ${ }^{71}$ Three committees were set up in 2017: the Audit and Risk Committee, Budget and Human Resources Committee, and the Policy and Strategy Committee.

art 11-2. Delegation of this authority requires approval by a majority representing not less than three-fourths of total voting power.

67 See AfDB Charter, art 32-2; AD в Charter, art 31 (ii); and EBRD Charter, art 27 (ii).

68 The Zedillo Report recommended that the IBRD Board delegate responsibility for the approval of all operations to Management, in order to remove the co-managerial role and eliminate the conflict of interest, and to strengthen accountability. Moving operational approvals to the President could also enhance flexibility and efficiency, and free up Board time and staff resources. Zedillo (n 63) para 128.

69 АІІв Charter, art $26(\mathrm{v})$.

70 ADв Charter, art 31 (iv); E BRD Charter, art 27 (iv); and IADв Charter, art viII, s 3 (i). The requirement to submit the annual budget approved by the Board of Directors to the Board of Governors for information is found in the АІІв By-Laws, s 5 (c). The approval and reporting requirements are found in the By-Laws for IBRD (s 18 (b)) and the General Regulations for $\operatorname{AfDB}$ (s 8-1).

71 АІІв Charter, art 26 (vi). The Board's power to appoint committees is found in the Charters for IADB (art VIII, s $3(\mathrm{i})$ ) and IBRD (art v, s $4(\mathrm{i})$ ). It is not found in the Charters for AfDB, ADB and EBRD; rather, ADB By-Laws (s 12) and EBRD Rules of Procedure of the Board of Directors (s 11) contain a similar power. The AfDB Board of Directors does also have a committee structure similar to these others. 
- Approving AIIB's balance sheet and statement of profit and loss is a reserved power of the Board of Governors. Submitting the audited accounts for each financial year for approval of the Board of Governors is the responsibility of the Board of Directors. This allocation of responsibilities is found in other MDBs as well, whether in the Charters as in AfDB, ADB and EBRD or in the By-Laws as in IBRD and IADB. ${ }^{72}$

\subsubsection{Board Oversight Mechanism}

In a provision unique to the AIIB Charter, the Board of Directors is expressly required to supervise the management and operation of AIIB on a regular basis. ${ }^{73}$ This general function is understood to be part of the Board's overall responsibility in other MDB Boards of Directors, so that making it explicit for AIIB adds more definition to the Board's role in the non-residential context, where physical presence is not an element of oversight. Indeed, the АІІв Charter further requires the Board of Directors to establish an oversight mechanism for this purpose, "in line with principles of transparency, openness, independence and accountability." The АІІв Chief Negotiators' Report records what the negotiators expected in respect of the oversight mechanism:

Representatives agreed that the oversight mechanism to be established by the Board of Directors under Article 26 (iv) would be designed in line with the principles of transparency, openness, independence and accountability, and would address such areas as audit, evaluation, fraud and corruption, project complaints and staff grievances, and reflect the Bank's character as a multilateral financial institution focused on infrastructure development.

The oversight bodies at other MDBs-such as evaluation, accountability, integrity and internal dispute resolution - have been added and refined over time, necessarily in a piecemeal fashion. Coming later, AIIB may be able to organize some of these functions in a coordinated way from the start. AIIB's oversight functions include: the anti-corruption and project complaint mechanisms under AIIB's Compliance, Effectiveness and Integrity Unit; the ethics rules for staff and Board; the internal and external audit offices and the Board's

\footnotetext{
72 АІІв Charter, art 26 (v). AfDB Charter, arts 29-2 (g) and 32-4; АDв Charter, arts 28-2 (viii) and 31 (iii); евRD Charter, arts 24-2 (viii) and 27 (iii); IADB By-Laws s 10; and IBRD ByLaws, s 18. 
Audit and Risk Committee; and the staff dispute resolution process under the AIIB Staff Regulations. ${ }^{74}$

\subsection{President}

The АІІв President is required to be a national of a regional member country, as in AfDB and ADB. ${ }^{75}$ The President is elected by the Board of Governors, by a Super Majority vote; some other M DBs also require a qualified majority vote for President, though a lower one. ${ }^{76}$ The Super Majority requirement, including 75 percent of the total voting power, ensures that the person elected has very substantial support from the shareholders, while it also could allow one or a handful of shareholders to exercise a veto.

That said, there have been unbroken nationality traditions for the heads of IBRD (US), the IMF (European) and ADB (Japanese), even where there is no

74 Elements of the oversight mechanism can be seen in outline on the AIIB website <www .aiib.org > accessed $3_{1}$ December 2017. For the anti-corruption function, see AIIB's Policy on Prohibited Practices (December 2016). For project complaints, a Complaints Handling Mechanism is under development. For ethics, see AIIB's Code of Conduct for Board Officials and Code of Conduct for Bank Personnel, approved by the Board of Governors at its Inaugural Meeting in January 2016. For audit, see the Audit and Risk Committee of the Board of Directors, which includes two external members. For staff dispute mechanisms, see AІів Staff Regulations (November 2016). External inputs and scrutiny are also provided by AIIB's International Advisory Panel, a group of worldwide experts that advises the President, and by the availability of АІІв information under its Public Information Interim Policy.

75 АІІв Charter, art 29-1. AfDB Charter, art 36-1 and AD в Charter, art 34-1.

76 АІІв Charter, art 29-1. A Super Majority vote requires two-thirds of Governors with threefourths of total voting power. This is higher than the majority votes required for election of the President at AfDB, ADB, EBRD, IADB and IBRD. AfDB Charter, art 36-1 and IADB Charter, art VIII, s 5 (a) (a majority of total voting power including a majority of total regional voting power); ADB Charter, art 34-1 and EBRD Charter, art 30-1 (a majority of Governors with a majority of total voting power).

Originally, the AfDB President was elected by the Board of Directors; this was changed to election by the Board of Governors by amendment of the AfDB Charter in 1979. AfDB Board of Governors' Resolution 05-79, Concerning the Amendments of the Agreement Establishing the African Development Bank to Enable Non-African Countries to Become Members Thereof, approved May 17, 1979, entered into force May 7, 1982, Annex, paragraphs 12 and 16.

In IBRD, the selection of the President is decided by the Executive Directors (the Board of Directors), not the Board of Governors, and by a simple majority. IBRD Charter, art v, s 5 (a). Until 2012, the selection was invariably announced as unanimous. In 2012, the announcement noted that the process had yielded multiple nominees, and that the final nominees received support from different member countries. "World Bank's Executive Directors Select Dr. Jim Yong Kim 12th President of the World Bank Group," World Bank Press Release, 16 April 2012. 
veto at play. ${ }^{77}$ To balance this history of nationality traditions, the АІІв Charter formally includes an open, transparent and merit-based selection process, a requirement that has been mentioned in other MDBs but not included in their Charters. ${ }^{78}$ The AII B Charter similarly provides for Vice-Presidents to be selected on the basis of an open, transparent and merit-based process; VicePresidents are appointed by the Board of Directors on the recommendation of the President, ${ }^{79}$ as in ADB, EBRD and IADB ${ }^{80}$ In addition, there is a two-term

77 The role of informal political arrangements regarding nationality of senior appointments in international financial institutions is well-documented. See, eg, Jacob Katz Cogan, "Representation and Power in International Organization: The Operational Constitution and its Critics," [2009] 103 AJIL 209, 227-229.

78 AIIB Charter, art 29-1. At IBRD, this process requirement can be seen in the Report on the Selection Process of the President, adopted by the IBRD Executive Directors, in response to Development Committee communiques calling for an open, merit-based and transparent selection process. Development Committee (formally known as the Joint Ministerial Committee of the Boards of Governors of the World Bank and International Monetary Fund on the Transfer of Real Resources to Developing Countries), Strengthening Governance and Accountability: Shareholder Stewardship and Oversight, Background Document (DC2011-00o6, 4 April 2011) Annex 2.

Similarly, the IMF process for the selection of the Managing Director has referred to an open, merit-based and transparent selection process following evolving reforms dating back to 2007. See, for example, Communiqué of the International Monetary and Financial Committee of the Board of Governors of the International Monetary Fund, 4 October 2009, para 5 .

79 АІІв Charter, art 30-1. As of December 2017, АІІв has 5 Vice-Presidents (Corporate Secretary, Chief Financial Officer, Chief Investment Officer, Policy \& Strategy, and Chief Administration Officer). AII B Senior Management also includes the General Counsel and Chief Risk Officer, appointed by the President. See AIı, Connecting Asia for the future, Annual Report and Accounts 2016 (AIIB 2017) 11. ADв Charter, 35-1 and EBRD Charter, art 31-1.

For IADB, the Executive Vice President and other Vice Presidents are also appointed by the Board of Directors on the recommendation of the President. IADB Charter, art viII, s 5 (b) and (c).

IBRD Charter, art V, $s 5$ does not refer to Vice-Presidents but only to officers and staff, all appointed by the President.

AfDB Charter, art 37-2 empowers the President to appoint Vice-Presidents, "provided that he shall act in consultation with the Board of Directors in the exercise of his powers of appointment and release of Vice-Presidents." Originally, AfDB Vice-Presidents were also appointed by the Board of Directors on the recommendation of the President; the AfDB Charter was amended to the language quoted by AfDB Board of Governors' Resolution B/BG/97/o5, Concerning Measures to Enhance Governance of the African Development Bank and Amending the Agreement Establishing the Bank, adopted 29 May 1997, entered into force 2 May 1998, para 5. 
limit for the AIIB President (each term is five years)..$^{81}$ AIIB's two-term limit is also found in AfDB and at IADB. ${ }^{82}$

The powers of the President under the АІІв Charter flow from the dual role as the chief executive of AIIB and as Chairman of the Board of Directors. As the Bank's chief executive, the President is "chief of the staff of the Bank" and conducts, under the direction of the Board of Directors, the current business of AIIB. ${ }^{83}$ Additional specific powers of the President include the responsibility for the organization, appointment and dismissal of officers and staff, in accordance with regulations adopted by the Board of Directors, ${ }^{84}$ and the preparation of the administrative budget to be presented to the Board of Directors for approval. ${ }^{85}$ As previously noted, the Board of Directors may also delegate authority to the President, including under Bank policies and for decisions on operations. ${ }^{86}$

\section{AII B Decision-making}

\subsection{Voting Power}

AIIB follows an MDв practice of weighted voting, rather than equal votes for each member. The total voting power of each AIIB member consists of the sum of its share votes, basic votes and, in the case of a Founding Member, its Founding Member votes. ${ }^{87}$

- Share votes. Share votes are equal to one vote for each share of stock held by a member. Larger shareholders consequently hold more share votes, and, as a result, rules for the allocation of capital subscriptions have an impact on relative voting power. Share votes are common in the MDBs, and underpin

81 АІІв Charter, art 29-2. The President's term is five years in AfDB (art 36-1), ADB (art 34-2) and IADB (art VIII, s 5 (a)) and four years at EBRD (art 30-1). The President's initial term in IBRD is also five years, and successive terms may be up to five years. IBRD By-Laws, s 13 (c).

82 AfDB Charter, art 36-1. For IADB, see Regulations for the Election of the President (s 2 (c)): "The Governors state their firm will that no President shall hold office for more than two consecutive terms of five years."

83 АІг Charter, art 29-4. By virtue of this clause, the President is also the legal representative of AIIB.

84 АІІв Charter, art 30-2.

85 AІІв By-Laws, s 5 (c).

86 АІІв Charter, art 26.

87 АІІв Charter, art 28-1. 
the weighted voting system that differentiates them from many other international organizations. ${ }^{88}$

- Basic votes. Basic votes are the same for each member, and are a common but not universal feature in MDBs. Basic votes provide an element of voting power that recognizes the equality of members, in contrast to the differentiated economic weight of members usually reflected in share votes. For AIIB, the exact number of basic votes is recalculated each time voting power is determined, to meet the requirement that the total number of basic votes allocated to all members must always equal 12 percent of total votes. The number of basic votes assigned to each member changes with changes in the number of share votes and Founding Member votes, and in the number of members. Basic votes have the effect of increasing the relative voting power of smaller shareholders (above their shareholding percentage) while reducing the relative voting power of larger shareholders (below their shareholding percentage). In AIIB (and ADB and IBRD), basic votes are set as a percentage, because setting basic votes as a fixed number of votes specified in the Charter in other cases has meant that a member's basic votes stayed the same while share votes increased with subscriptions to stock. Using a fixed number gradually reduced the weight and benefit of basic votes. ${ }^{89}$

- Founding Member votes. Founding Member votes are fixed at 600 votes per member. Founding Member votes are assigned to those Signatories who

88 See AfDB Charter, art 35 (share votes and 625 basic votes); АD в Charter, art 33 (share votes and 20 percent basic votes); EBRD Charter, art 29 (share votes only); IADB Charter, art VIII, s 4 (share votes and 135 basic votes); and IBRD Charter, art v, s 3 (share votes and 5.55 percent basic votes).

89 When the concept of basic votes was introduced in IBRD in 1945, each member had 250 votes (basic votes) plus one vote for each share of stock held (share votes). (IBRD Charter, art v, s 3 (a), prior to its amendment in 2012.) Originally, IBRD basic votes represented about 11 percent of total voting power (basic votes plus share votes). Over time, each member's basic votes remained at the fixed number, while the overall number of share votes increased with each increase in IBRD capital and shares held by members. As a result, IBRD basic votes represented only 2.86 percent of total voting power when voice reform discussions were underway in the mid-200os. As part of those reforms, the IBRD Charter was amended to set basic votes as a percentage of total votes, equal to 5.55 percent of total votes, so that the proportion of basic votes would be maintained when share votes increase. In $\mathrm{ADB}$, basic votes have been at a percentage of total votes (20 percent) since the beginning; a fixed number of basic votes was set in the original Charters for AfDB (625) and IADB (135), now less than 1 percent of total voting power in each. See $n 92$ for Charter references. 
become Founding Members by completing membership requirements before the deadline set in the АІІв Charter. ${ }^{90}$

- Under the original allocations in Schedule A of the AIIв Charter, the weight of all Founding Member votes in total AIIB voting power would have been around 3 percent. Combined with the weight of total basic votes (12 percent), that would mean that votes not tied to shareholding would account for about 15 percent, and votes tied to shareholding would weigh about 85 percent. This compares with an 80 percent weight for share votes in ADB (2o percent basic votes) and a 94.5 percent weight for share votes in IBRD (5.5 percent basic votes); in AfDB and IADB, share votes account for over 99 percent of voting power, and in EBRD, share votes are 100 percent of voting power (no basic votes).

\subsection{Qualified Majorities}

In general, decisions by the AIIB Board of Governors and the Board of Directors require a majority of votes cast. ${ }^{11}$ For the Board of Governors, there are two types of higher majority votes (qualified majorities): a Super Majority vote requires an affirmative vote of two-thirds of the total number of Governors, representing not less than three-fourths of the total voting power of the members; and a Special Majority vote requires an affirmative vote of a majority of the total number of Governors, representing not less than a majority of the total voting power. ${ }^{92}$ Super Majority decisions are usually key institutional matters, and include: capital increases; individual members subscription increases, modifying the regional shareholding percentage; provision of assistance to non-members; increase in the lending limit; allocation of net income to "other purposes"; changes in the Board of Directors; modifying the non-resident basis for the Board of Directors; election of the President; and amendment of the Charter. ${ }^{93}$ Other institutionally important decisions require a Special Majority

90 AIIB art 3-1 (b). As of January 2018, AII B had 54 Founding Members and the deadline for completion of membership requirements by the remaining three Signatories under art 58-1 had been extended to 31 December 2018.

91 АІІв Charter, art 28-2 (i) and 28-3 (ii).

92 АІІв Charter, art 28-2 (ii) and (iii).

93 АІІв Charter, art 4-3 (increase in capital), art 5-3 (increase of a subscription of a member), art 5-2 and 5-3 (modifying the percentage of capital stock held by regional members), art 11-1 (b) (provision of assistance to non-members); art 12-1 (increase in the lending limit), art 18-1 (allocation of net income to other purposes), art 25-2 (changes in the size or composition of the Board of Directors), art 27-1 (modifying the non-resident basis for the Board of Directors), art 29-1 and 29-2 (election of the President; removal or suspension from office), art 38 (suspension or restoration of membership), art 41 (termination of operations), art 43-1 (ii)(distribution of assets), and art 53-1(amendment of the Charter). 
vote, including: admission of members; approval of other types of financing; and establishment of subsidiaries. ${ }^{94}$

Qualified majorities for Governors' decisions have been streamlined in the AIIB Charter, into these two clearly defined categories, Super Majority and Special Majority. Other MDBs also have qualified majorities for many similar decisions, and in most cases, the percentage of total voting power required is 75 percent. ${ }^{95}$ The most notable exceptions are at IBRD (Charter amendment requires 85 percent and changing the number of Executive Directors requires 80 percent), ${ }^{96}$ and at EBRD (Charter amendments require an 80 percent majority and certain decisions on country access to its resources require an 85 percent majority). ${ }^{97}$ In IAD B and AfDB, some decisions require separate qualified majorities for regional and non-regional members. ${ }^{98}$

Amendments of the AII B Charter require a Super Majority vote, except that unanimity is required to amend: (i) each member's right to withdraw from the Bank; (ii) the limitations on liability of members; and (iii) the pre-emptive rights pertaining to purchase of capital stock. AII B Charter, art 53-1 and 53-2. Other MD Bs have similar unanimity requirements. AfDB Charter, art 60-3; АD В Charter, art 59-2; Е ВRD Charter, art 56-2 (adds to the list amendments to its purpose and functions); IADB Charter, art XII (b) (slightly different); and IBRD Charter, art VIII (b).

94 AІІB Charter, art 3-2 (admission of members), art 7-1 (issuance of non-par stock), art 112(vi) (approval of other types of financing), art 16-8 (establishment of subsidiaries) and art 58-1 (extension of the deadline for deposit of instruments of ratification).

95 For a detailed comparison of qualified majorities, see Lichtenstein $\left(\mathrm{n}^{*}\right)$, Table 7.4.

96 IBRD Charter, art v, s 4 (b) (Governors representing four-fifths majority of total voting power to increase the number of Executive Directors) and art VIII (a) (three-fifths of members having 85 percent of total voting power to amend the Charter).

97 EBRD Charter, art 56-1 for Charter amendments (three-fourths of members, including at least two Central and Eastern European countries, holding four-fifths of total voting power). The EBRD majority for access decisions is three-fourths of the Governors representing 85 percent of the total voting power. ЕBRD Charter, art 8-4 (iii).

98 Specific regional majorities were introduced with the advent of non-regional membership in IADB, and later in AfDB. These include:

- capital increases (not in AfDB; IADB Charter, art II, s 2(e));

- changes in composition of the Board of Directors, with a special regional majority for changes in regional rules (AfDB Charter, art 33-1; IAD B Charter, art VIII, s 3(b)(ii));

- election of the President (AfDB Charter, art 36; IADB Charter, art viII, s 5 (a));

- quorum for the Board of Governors and for the Board of Directors (AfDB Charter, arts 31-2 and 34-2, later amended to delete the regional majority and require 70 percent of total voting power; IADB Charter, art VIII, ss 2 (e) and 3 (f));

- suspension of membership (AfDB Charter, art 44, later amended to delete the regional majority and require $70 \%$ of total voting power; IAD B Charter, art IX, s 2-depending on whether the member is regional or non-regional);

- termination and distribution of assets (AfDB Charter, art 47-1, later amended to delete the regional majority and require 70 percent of total voting power and art 49-1 (ii), later amended to delete any qualified majority; IADB art X, ss 2 and 4 (a)); and

- amendment (AfDB Charter, art 6o-1; IADB Charter, art XII (a)). 
For the AІів Board of Directors, there are three qualified majority decisions (requiring 75 percent of total voting power), as already discussed: (i) approval of major operational and financial policies; (ii) delegation of authority to the President under Bank policies; and (iii) delegation of authority to take decisions on operations. ${ }^{99}$ Boards of Directors in other MDBs generally operate without formal votes, although voting power plays a role in reaching agreement. In AIIB, this mechanism can be seen in the Board's Rules of Procedure, which follows other precedents in providing that the Chairman shall ordinarily ascertain the sense of the meeting without a formal vote, although a Director may require that his views be recorded or that a formal vote be taken. ${ }^{100}$ While actual voting is rare, the voting power represented by each Director would be taken into account in ascertaining the sense of the meeting as to whether a majority of voting power would be in favor of the decision taken.

Two additional aspects of decision-making are often influential. First, voting power is heavily dependent on shareholding in АІІв as elsewhere, as noted above. Shareholding in turn depends on the rules for allocation of capital subscriptions. For AIIB, the basic principle and parameters have been established in the AIIB Chief Negotiators' Report as the relative share in the global economy. ${ }^{101}$ Using economic strength to guide shareholding reflects the essential role of capital subscriptions in the MDв financial structure, as the capital market finance raised by the мDв relies in large part on the financial strength of the callable capital commitments of the MD в shareholders. ${ }^{102}$ Secondly, АIIв follows other regional $\mathrm{MDBS}$ in maintaining a minimum regional shareholding (75 percent). ${ }^{103}$ Both of these factors play a role when considering the possibility of veto power, which is another dimension of MDB governance.

99 AIIB Charter, art 26 (ii) and (iii). EBRD requires a two-thirds' majority for policy decisions of the Board of Directors. See $\mathrm{n} 6 \mathrm{~g}$ for more details.

100 AIIB Rules of Procedure of the Board of Directors, s 5 (a). See AFd B Rules of Procedure of the Board of Directors, s 8-1; ADB Rules of Procedure of the Board of Directors, s 5 (a); EBRD Rules of Procedure of the Board of Directors, s 5 (a); IADв Regulations of the Board of Executive Directors, Part III, s 3 (a); and IBRD Rules of Procedure for Meeting of the Executive Directors, $\mathrm{s} 4$.

101 The АІгв Chief Negotiators' Report states, as to allocation of capital: "Representatives noted that the basic parameter for allocation of capital stock to members would be the relative share of the global economy of members within the regional and non-regional groupings, respectively. Members' shares of the global economy would be measured by reference to Gross Domestic Product (GDP), with the understanding that GDP share would be indicative only for non-regional members."

102 Lichtenstein $\left(\mathrm{n}^{*}\right)$, paras 6.03-6.05.

103 AІІB Charter, art 5-2 and 5-3. 


\section{$5 \quad$ Conclusions}

From the preceding discussions, we can see that AIIB has maintained a basic MDB governance model while making its own modifications, as others have before. Among these adaptations, AIIB's Board of Governors has additional powers to allow AIIB to respond to changes over time, without forcing AIIB to fit new initiatives within unchangeable rules, provided there is sufficient consensus among the members. ${ }^{104}$ AIIB's Board of Directors follows the practice of a few MDBs and is non-resident, with clearly provided powers to approve policy and operations, delegate authority and supervise management; its oversight powers are highlighted. AIIB's President has traditional powers with the express possibility of delegated authority, and is limited to two terms. The selection of the President and Vice-Presidents through an open, transparent and merit-based process sets a new legal standard. The desirability of a greater voice for regional and smaller members is recognized by adding a second Alternate Director for larger Board constituencies, rotation privileges for Founding Members and the 12 percent weight for basic votes.

In terms of legal structure, the interplay of the legal provisions in the AIIB Charter and the parties' agreements recorded in the Chief Negotiators' Report gives AIIB a firm basis for adjusting to changes in the future. By providing specifics on such matters as GDP as the basic parameter for capital allocation, the Chief Negotiators' Report keeps today's details clear and transparent without enshrining them in the АІІв Charter where they may someday become outdated. Should Charter amendment become necessary, the АІ в В Charter follows a model that requires a high-majority Board of Governors decision without mandating an additional approval process under each member's domestic procedures.

In sum, AIIB's governance features both MDB heritage and innovation, as AIIB takes its place in the family of MDBs.

104 Examples of flexible provisions in the АІІв Charter include variation in the definition of the Asia region (art 1-2), modification of the 75 percent regional shareholding requirement (art 5-2 and 5-3), financing in non-member territory (art 11-1 (b)), introduction of new types of financing (art 11-2 (vi)), increase in the lending limit (art 12-1) and changing the non-resident status of the Board of Directors (art 27-1). 